
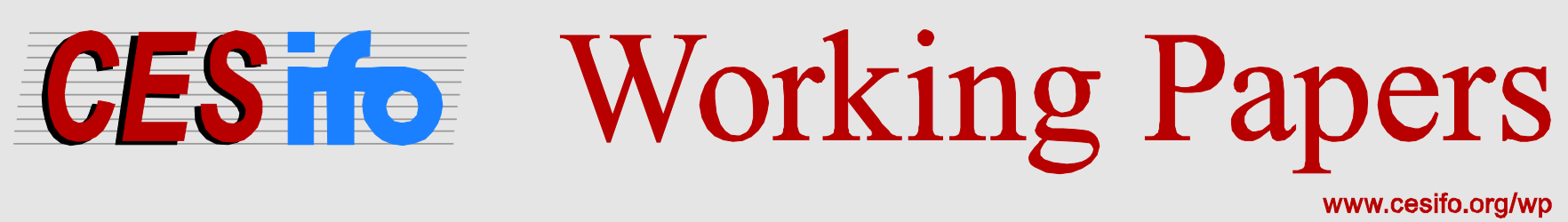

\title{
Taxes in an E-Commerce Generation
}

\author{
David R. Agrawal \\ William F. Fox
}

CESIFO WORKING PAPER NO. 6050

CATEgory 1: Public FinANCE

August 2016

An electronic version of the paper may be downloaded

- from the SSRN website:

- from the RePEc website:

- from the CESifo website: WwW.SSRN.com

Www.RePEc.org

www.CESifo-group.org/wp 


\title{
Taxes in an E-Commerce Generation
}

\begin{abstract}
Rapid growth in e-commerce has altered the ability of jurisdictions to enforce commodity taxes on a destination basis. This results in different effective tax rates depending on the way in which goods and services are purchased and the characteristics of both the products and the sellers. We discuss the arguments for the destination principle as the appropriate place-of-taxation rule for consumption taxation of cross-border trade. We analyze various recent reforms to the Value Added Tax in the European Union in response to e-commerce. We then examine various policy options in the United States - maintaining the status quo, changing nexus rules, states adopting information reporting, and national reforms that require firms to remit taxes regardless of physical presence - and relate them to the recent European reforms. We conclude based on our analysis and the recent European Union experience that reforms at the national level appear to be the important next step to enforcing commodity taxes at destination in the U.S.
\end{abstract}

JEL-Codes: H200, H700, L810, R500.

Keywords: destination taxation, origin taxation, commodity taxes, online shopping, ecommerce, tax competition, digital products.

David R. Agrawal

University of Kentucky

Martin School of Public Policy \&

Department of Economics

USA - Lexington, KY 40506-0027

dragrawal@uky.edu
William F. Fox

University of Tennessee

Center for Business \& Economic Research

715 Stokely Management Center

USA - Knoxville, Tennessee 37996-0570

BillFox@utk.edu

May 16, 2016

The authors are grateful to Nathan Anderson, Richard Bird, John Brooks, Walter Hellerstein, Jeffery Hoopes, Matthew Murray and David Wildasin as well as participants at the National Tax Association Conference on Taxation for comments on earlier drafts of the paper. The comments of two anonymous referees and the editor, Albert Solé-Ollé, improved the paper. A longer version of this paper containing more U.S. specific institutional details and more extensive literature coverage was titled "Sales Taxes in an e-Commerce Generation" and is available online or from the authors. The authors are responsible for all remaining errors. 


\section{Introduction}

Issues of cross-border shopping and mail order catalogs have long challenged administration of indirect taxes on a destination basis. ${ }^{1}$ However, rapid growth in online transactions and the expansion of digital products - such as video streaming, cloud-based storage, and smartphones place new pressures on destination-based, subnational transaction taxes, like state and local retail sales and use taxes in the United States. For example, the location of both consumption and sale for digital products is difficult to define and imperfect enforcement capacity allows many remote transactions to effectively escape taxation because they are not taxed at origin or destination. New technologies and digital products challenge the design of decentralized commodity taxes in other countries as well. Canada operates a Goods and Services Tax (GST) with federal and provincial rates; Value Added Tax (VAT) rates vary within the European Union (EU); and India and Brazil levy state-level rates through their tax systems. Even highly centralized tax systems are not immune to the pressures of e-commerce. For example, New Zealand's Prime Minister recently indicated that the country is losing significant revenue associated with online and digital transactions and efforts will be made to enhance enforcement. ${ }^{2}$ Given e-commerce is ubiquitous and poses challenges regardless of the country-specific tax system, one major goal of this paper is to link these policy challenges and reforms abroad to the United States context.

The economics literature devotes considerable attention to whether taxes should be levied on a destination or an origination basis (Keen, Lahiri, and Raimondos-Møller, 2002). The destination principle has frequently been chosen - often on production efficiency grounds given that competitive firms in different states will have the same marginal cost of production. But, ecommerce and other emerging technologies could ultimately cause this decision to be

\footnotetext{
${ }^{1}$ See U.S. Advisory Commission on Intergovernmental Relations (1994).

${ }^{2}$ See "Retailers Back GST for Online Overseas Shopping," New Zealand Herald, March 18, 2015.
} 
reconsidered or at least require significant administrative improvements. Existing practices leave governments in the U.S. and EU potentially using an odd combination of both origin and destination taxes for e-commerce transactions. As a result of court decisions, U.S. states cannot use vendors to enforce destination taxes for cross-state e-commerce transactions when the vendor does not have physical presence in the buyer's state and states must resort to attempts to collect the tax from buyers. The EU collects commodity taxes on a destination basis for digitized transactions, though the ability to enforce a collection responsibility on remote vendors, and particularly those located outside the EU, appears uncertain. ${ }^{3}$ For remote goods, the VAT operates on either a destination or origination basis depending on the size of vendor's sales to a country and the characteristic of the good (digital or physical).

This survey contributes by examining how the rapid growth in e-commerce has exacerbated governments' difficulties in collecting sales taxes on a destination basis is threefold. First, although our emphasis is on U.S. reforms, we present information on how e-commerce affects destination taxation from an integrated global perspective; most other studies of ecommerce focus on a specific country. In this regard we state clearly how the EU has implemented reforms on remote transactions and digital products that are relevant to the U.S. scenario. The European experience is then discussed in the context of recent U.S. struggles to enforce destination taxation because countries like the United States have much to learn from recent EU reforms. Second, we analyze the implications of a long list of reasonable policy reforms in the United States that have been proposed to solve the concerns arising from ecommerce. Given the recent developments in the United States, no studies outline or analyze all the reforms on the table and those studies that analyze some reforms do so in a starkly American

\footnotetext{
${ }^{3}$ Under the EU VAT, problems of enforcement differ on business to business and business to consumer transactions because of the self-assessment method on business to business transactions.
} 
context that fails to draw lessons from the ubiquitous nature of e-commerce. Third, we make specific U.S. policy recommendations for taxation at destination. We argue that a national solution such as passage of the Marketplace Fairness Act is likely the next necessary step.

\section{Trends in U.S. E-Commerce}

E-commerce has grown rapidly in the U.S. as it has in many countries. The U.S. Census Bureau reports that e-commerce sales totaled $\$ 1.06$ trillion in 2000 and grew at a compound annual rate of about 14 percent until 2013 when they reached $\$ 5.14$ trillion. ${ }^{4}$ Much of e-commerce is intermediate goods sales. ${ }^{5}$ About 87 percent of e-commerce sales are made by manufacturers and wholesalers, with retailers and service firms accounting for the rest. Most, but not all, sales by manufacturers and wholesalers are intermediate transactions and some sales by retailers are to other businesses, so intermediate sales probably dominate e-commerce. Retail e-commerce now accounts for 66.9 percent of remote retail sales with mail order representing only 33.1 percent.

Significant components of e-commerce transactions are subject to the sales tax since almost all purchases that are taxable when obtained through traditional channels are also taxable when bought online. In all likelihood, most of the tax that is due is being collected. Still, estimates are that about $\$ 12$ billion in sales taxes went uncollected in 2012 , which represented about 3.8 percent of sales tax collections that year, and the revenue loss has grown in the intervening years (see Bruce, Fox and Luna, 2009).

\section{Institutions: Sales Taxes in the United States and Around the World}

\section{A. State and Local Sales Taxes}

Sales taxes are levied by 45 U.S. states and local governments in over 35 states (Agrawal, 2014). Local governments in many states control the local sales tax rate, but in some, such as Virginia,

\footnotetext{
${ }^{4}$ Authors calculations using data from http://www.census.gov/econ/estats/2013/all2013tables.html

${ }^{5}$ Sales taxes are often imposed on intermediate transactions. See Wildasin (2001) and Bruce, Fox and Luna (2009).
} 
the rate is set by the state for all local governments (although it is not set uniformly). At the other extreme is Louisiana, where local governments control their base, rate and administration. Administration of the local sales tax is by the state in many states (Tennessee) and is by local governments in others (Louisiana). Private firms are often hired to administer the tax in places where local governments are responsible for administration.

Vendors can only be required to remit the sales tax for states where they have the minimum Constitutional presence necessary, referred to as nexus. Nexus is not specifically articulated in the Constitution, but must be inferred. ${ }^{6}$ We discuss definitions of nexus below. The aggregate sales tax base across all states has diminished since at least 1979, with large declines during recession years and only partial recovery during expansion years. The general propensity to tax goods but only a limited set of services is one cause of base erosion (see Fox, 2012). Taxable services in most states do not include the faster growing services, such as health care, other professional services, and contractor services. As goods consumption has risen more slowly than non-taxable services, the base has fallen relative to personal income. This issue does not generally arise in countries with a VAT. State policies to exempt new items, including food in many states, clothing in several states, and tax holidays, are a second cause of eroding sales tax share. Third, rapidly increasing remote sales on which the sales tax is not collected have exacerbated the problem and must be placed in the context of these other changes.

\section{$\underline{\text { B. Destination Structure }}$}

\footnotetext{
${ }^{6}$ The U.S. Supreme Court established the physical presence requirement in the 1967 case of National Bellas Hess, Inc. v. Department of Revenue. The 1992 ruling commonly referenced (Quill Corp v. North Dakota (504 US 298 (1992))) simply reiterated that holding. Indeed, in the case of Quill, several Justices concurred solely on the basis of the doctrine of stare decisis (literally "let the decision stand," and more generally the doctrine that requires respect for precedent). Supreme Court Justice Kennedy recently argued that the decision should be reconsidered (Direct Marketing Association v. Brohl, 134 S. Ct. 2901 (U.S. 2014)). Justice Kennedy referred to the revenue loss for state and local governments in his argument.
} 
The combination of sales and use taxes creates a system that approximates destination taxation. Vendors generally collect and remit sales taxes (though this is limited by the physical presence requirement), which means that tax is collected at point of purchase when possession takes place, regardless of residence or where consumption actually occurs. Also, every sales taxing state subsequently enacted a corresponding use tax. ${ }^{7}$ Use taxes shift the legal incidence of the tax, which in many states shifts the responsibility for tax remittance from the seller to the buyer in cases where the tax was not collected by the seller. ${ }^{8}$

Sourcing at least some e-commerce sales on a destination basis is problematic and strong rules-based administrative efforts could generate new distortions. For example, clearly defining the places of sale and use for digitized products can be difficult and e-commerce often shifts tax compliance from the vendor to the buyer facilitating tax revenue leakages. Destination could be determined by billing address of a credit card, but this is easily evaded with electronic cash and other mechanisms. Behavioral responses and distortions can be large. For example, buyers have the incentive to self-report receipt in low tax jurisdictions. Such problems are not new because consumers have long had the incentive to travel across borders to make purchases at lower tax rates or to have goods shipped with no tax included, but e-commerce facilitates the evasion.

\footnotetext{
${ }^{7}$ Both households and businesses can owe use tax on their purchases in certain cases where the sales tax was not collected. Specifically, the use tax is levied when (1) out-of-state purchases are taxable in the destination state, (2) the items are brought into the destination state for use or storage and (3) the sales tax was not paid at point of purchase or was paid at a lower rate at the point of purchase in another state. Use taxes are also imposed when a firm makes exempt intermediate purchases, such as for resale, but converts the item to a taxable use.

${ }^{8}$ In email correspondence with us, Walter Hellerstein writes (with only light editing by us): Legally, use tax were enacted to shift the legal incidence of the tax from the "sale," which was thought to be constitutionally barred when the sale was in "interstate commerce," to the in-state "use," which was constitutionally unobjectionable. Use taxes were not legally designed to shift the collection responsibility from the vendor to the purchaser. However, there have been changes over the years that have attempted to do this (including the line on some state income tax returns that asks purchasers to self-report the use tax) and in certain instances (e.g., use tax on cars purchased outside the state upon registration).
} 
States differ in how they impose use taxes for local governments. As already noted, destination is often presumed to be where possession is taken, so store location often defines destination for local taxes, independent of where buyers live. In many cases local use taxes arise when goods are purchased from out of state, via e-commerce or through other means. But, some states (Illinois, Missouri, and Tennessee, for example) do not collect on a destination basis inside the state, but instead collect an origin local tax rate at point of sale even when the goods are shipped from one in-state jurisdiction to another. Presumably origin sourcing of local taxes limits compliance costs compared with costs of applying multiple tax rates at destination.

State and local use tax compliance is regarded as extremely weak, particularly for households. Vehicles, boats and planes provide an exception because they must be licensed. Some evasion occurs when buyers plan the location of where to house these licensed items, but this evasion is likely modest. A series of audits conducted by the state of Washington (2010) determined that business compliance with the use tax is the weakest of any state tax imposed on business, with non-compliance estimated to be 23 percent (one percent for the sales tax).

In sum, the inability to enforce the use tax successfully on e-commerce and digitized goods likely results in lower effective tax rates than for goods and services purchased locally, even though the same tax rate is generally statutorily levied on similar goods and services regardless of the channel through which they are purchased.

\section{Origin and Destination Principles in Europe with Respect to e-Commerce}

Countries that have adopted a VAT or Goods and Service Taxes, including those in the European Union, also have expressed concerns about electronic commerce and digital products. ${ }^{9}$ Several possibilities arise as to whether the origin or destination principle applies when the supplier and

\footnotetext{
${ }^{9}$ See McLure (2003) for discussion of some VAT related issues in the European Union.
} 
customer are located in different countries within the EU and the goods are sent to the

customer. ${ }^{10}$ The origin principle applies to cross-country sales by smaller firms except for

digitized services. However, if sales in a particular member state exceed a threshold (that varies

by the destination country) or if the suppliers opt to do so (likely if the firm locates in a very high

VAT country), then taxes are assessed on a destination basis. Suppliers of digital services that

are located in countries outside of the EU as well as those inside the EU are expected to assess

VAT based on the destination principle when they make sales in the EU. ${ }^{11}$

\section{Tax Policy and E-Commerce}

With perfect enforcement, the combination of sales and use taxes imposes uniform statutory

levies on transactions consummated via e-commerce and via local shopping. ${ }^{12}$ Differences

between the taxation of in store and e-commerce sales arise through administrative practices and

compliance behavior, meaning preferential treatment for e-commerce occurs because buyers are

better able to evade taxes on remote than on in store purchases. ${ }^{13}$ Vendor audits are much more

common and effective than consumer use tax audits, making the sales tax harder to evade than

the use tax. Of course, many retailers operate through multiple channels, so the potential for

evasion depends on who the buyer is and where the buyer is located. ${ }^{14}$ Before discussing policy

\footnotetext{
${ }^{10}$ See the European Commission's discussion of "Mail order and distance purchasing" available at http://ec.europa.eu/taxation_customs/taxation/vat/consumers/mail_order_distance/index_en.htm

${ }^{11}$ Some jurisdictions in the United States have also extended taxing authority to products streamed to businesses and consumers (the so called "cloud tax"). See "Chicago Extends Taxing Power to Online Movies, Music, More," Chicago Tribune, July 2, 2015.

12 This statement is not strictly true since some differences exist as state statutes have been slow in adapting to changing technologies. For example, digitized transactions such as music or video may not be taxable in some states while the tangible version of the same content (CDs, DVDs, etc.) is taxable. Mazerov (2013) summarizes some of these differences. Also, as noted above, local use taxes are not always equal to local sales taxes.

${ }^{13}$ Many studies (Goolsbee, 2000; Ballard and Lee, 2007; Ellison and Ellison, 2009; Alm and Melnik, 2010; Goolsbee, Lovenheim, and Slemrod, 2010; Alm and Melnik, 2012) analyze the sensitivity of e-commerce to differential effective sales tax rates. Although the estimated elasticities vary across the papers, the majority of this literature finds large responses of online transactions to sales taxation suggesting that sales taxes and e-commerce have important economic interactions.

${ }^{14}$ Fox, Luna and Schaur (2014) find that more transactions take place from a greater distance at higher sales tax rates, apparently evidencing the greater capacity for evading the use tax as distance from the destination state rises.
} 
regimes we need to convince the reader the current treatment of e-commerce is sub-optimal. We proceed by discussing: i) whether e-commerce should be preferentially taxed relative to local store purchases, ${ }^{15}$ ii) how compliance/administration issues alter optimal tax rules, iii) how ecommerce affects tax competition, and iv) whether destination taxes are preferred.

\section{A. Optimal Tax Rules and E-commerce}

When are preferential tax rates for online transactions - mostly resulting from imperfect enforcement - optimal?

The optimal tax literature can be drawn on if online and in-store goods are seen as different commodities. This is because using a characteristics based approach, the time to receive the good, the convenience of ordering, the location of sale, the ease of comparison shopping and getting consumer reviews, and benefits of home delivery relative to traveling to crowded shopping malls, are all important attributes that differentiate goods. Optimal tax rules generally do not indicate identical commodity tax rates for either final or intermediate goods, though uniform taxes are optimal under certain conditions (Hatta, 1986). ${ }^{16}$ But, it would be coincidental for differences in demand and other characteristics across e-commerce and in store sales to parallel the conditions for differences in optimal tax rates. ${ }^{17}$ Effectively, the optimal tax rates would need to vary with the propensity for vendors to have taxable presence in a state and the propensity for the purchaser to have the capacity to and choose to evade the use tax. ${ }^{18}$

\footnotetext{
15 This section draws from Bruce, Fox and Murray (2003). Also, see Zodrow (2006).

${ }^{16}$ Uniform commodity taxation is often optimal if an income tax is also available, as is typically the case, and that the Ramsey rule on inverse elasticities is applicable only under very narrow circumstances.

${ }^{17}$ Further, the case for disparities in taxation for the same input obtained in stores versus e-commerce relies on firms viewing these goods as different so that the elasticities of substitution are altered between them. Presumably, producers are less likely than consumers to have qualitative linkages to how goods are obtained, and generally purchase based on lowest total costs though even businesses may be inclined to think of digitized products as different from physical ones.

${ }^{18}$ The theoretical logic is that taxes on e-commerce have a greater distortionary effect than taxes on in store sales. Much of the reasoning is that the inability to tax leisure means that efficiency loss is not minimized by taxing all goods uniformly because the substitutability between leisure and various goods differs. The optimal second best tax
} 
Zodrow (2006) demonstrates the somewhat more stringent condition that the case for preferential taxation of e-commerce requires that it yield a net increase in the supply of labor. Zodrow (2006) also finds that preferential rates for e-commerce are harder to justify with equity concerns in the model and when higher income people purchase more heavily via e-commerce. ${ }^{19}$

For these differences in elasticities to arise, the characteristics of online goods must be different than in-store goods. Einav, Knoepfle, Levin and Sundaresan (2014, p. 12) estimate the elasticity of online goods to be greater than 1.5 in absolute value for most online commodities and in excess of 4 for electronics. Compared to the most recent estimates of cross-border elasticities - approximately unity (Tosun and Skidmore, 2007) - the responsiveness of online goods seems to be larger. However, such a comparison is likely inappropriate because these elasticities partially capture substitution from one online platform to another and thus cannot be used to directly determine the optimal tax rates for online products; the type of goods being analyzed also differ across the studies.

\section{B. Optimal Taxation and Compliance and Administration}

Difficulties in administering differential rates and the propensity to adopt politically motivated rather than efficiency motivated differential rates enhance the case for uniform rates across remote and brick-and-mortar purchases. Zodrow (2006) finds two conflicting effects from administrative costs. First, the seemingly unexpected result is that higher taxes should be

\footnotetext{
system rests on taxing goods that are complementary with leisure more heavily (Slemrod, 1990), so the case for taxfavoring e-commerce must be based on a presumption that e-commerce is more highly substitutable with leisure than in-store sales.

${ }^{19}$ As noted in correspondence with David Wildasin: There is a case for differential taxation of identical goods (random taxation). Suppose that the demand functions for electricity are the same in different regions and the (compensated) demand is strongly convex. If we arbitrarily impose a high tax rate in one region and a low rate in the other, so as to maintain constant revenue, I can produce an efficiency gain, raising more revenue in the market where elasticity (at the margin) is low, and less where it is high. Thus, it is conceivable that differences in tax rates on e-commerce and brick/mortar could be efficiency improving, not because the commodities are different, but because the demand curve is sufficiently convex.
} 
imposed on e-commerce if it entails relatively large administrative costs in order to increase demand for goods where administration is less costly. Second, lower taxes on e-commerce are preferred if it is more substitutable with leisure. Overall Zodrow (2006) concludes that the case is much stronger for uniform taxation than for exemption of e-commerce.

A requirement that companies collect sales taxes for all states should add relatively few new companies in aggregate as most companies are already complying for at least one state. All firms located in at least one of the 45 sales taxing states should be remitting sales taxes on instate sales and in any other states where they have nexus. So, the added compliance costs for most firms are associated with collecting sales tax for additional states, and not with first time collection. ${ }^{20}$ Firms could be required to comply across all 45 sales taxing states if steps were taken to enhance compliance, so a significant increase could occur in the number of states where many firms comply. ${ }^{21}$ Some economies of scale might be expected as a firm collects for additional states, but differing bases and rates across jurisdictions add to the compliance burden.

The sales tax is operated separately by each state and these jurisdictions would need to administer significantly more taxpayers if firms complied in every destination state. On the other hand, greater sales tax compliance should reduce use tax (buyer) compliance costs providing some compliance and administration offset. Costs would also fall since the uncertainty of being audited would be reduced for buyers.

Relatively little is known about sales tax compliance costs but some data are available from PriceWaterhouseCoopers (2007), which estimated that sales tax compliance costs were

\footnotetext{
${ }^{20}$ Only nine firms in the 2012 sample of 293 relatively large firms selling via e-commerce (and often through other channels as well) in a survey used by Bruce, Fox and Luna (2015) do not have a sales tax collection responsibility in any state. The nine firms operate from non-sales taxing states.

${ }^{21}$ The data in Bruce, Fox and Luna (2015) include 164 firms with nexus in fewer than 10 states and only 69 firms with nexus in more than 40. Dollars of e-commerce sales and a count of number of states where nexus exists are positively correlated so the current tendency towards nexus in a small number of states would be much larger for the population of e-commerce firms, which would include a much greater concentration of small e-commerce firms.
} 
13.5 percent of tax revenues for small retailers, 5.2 percent for medium retailers, and 2.2 percent for large retailers. ${ }^{22}$ Bruce and Fox (2013) find the vast majority of e-commerce firms are small, suggesting significant compliance costs, though firms with over \$1 million in sales account for about 57 percent of business-to-consumer e-commerce. PriceWaterhouseCoopers finds that local sales taxes raise costs further, with one jurisdiction increasing costs by 38.7 percent and two or more adding 70.7 percent. Technology improvements have surely eased the burdens for both administration and compliance during intervening years. Tax compliance software can be purchased and firms may be able to comply at much lower cost today. For example,

Amazon.com provides fulfillment services for firms operating on its platform, including sales tax compliance for a relatively low percentage of tax revenues.

\section{Preferential Tax Regimes and Tax Competition}

How does an effectively lower rate for online commerce affect tax rates when jurisdictions compete with each other for a mobile sales tax base?

When the use tax can be easily evaded, the Internet acts in some ways like a tax haven that may have both positive and negative effects on state and local sales tax rates. The literature studying tax havens is divided on whether the presence of low-tax jurisdictions is parasitic or welfare enhancing. When tax havens are parasitic, elimination of tax havens will improve social welfare in other jurisdictions because they are better able to raise tax rates that were previously selected in order to compete with the tax haven for mobile resources (Slemrod and Wilson 2009). However, tax havens may be beneficial when countries are asymmetric because tax havens make it less attractive to compete for mobile factors and their presence may induce low-tax (but not tax haven) countries to become high-tax countries (Johannesen, 2010).

\footnotetext{
${ }^{22}$ Small companies are defined as ones with revenues between $\$ 150,000$ and $\$ 1,000,000$, medium companies as ones with receipts between $\$ 1,000,000$ and $\$ 10,000,000$ and larger companies are above $\$ 10,000,000$.
} 
Agrawal (2015) studies the effects of the Internet on tax competition and tax rates.

Agrawal shows that when consumers have the choice of buying online, buying from their home town and buying from a neighboring town, the Internet will put downward pressure on tax rates if the online transactions are tax free, and this downward pressure will be most pronounced in local jurisdictions setting high tax rates in the pre-Internet era. If, on the other hand, online firms remit taxes in all jurisdictions, an increase in Internet usage will raise tax rates because the online firm remits taxes on a destination basis reducing tax avoidance. The first of these two extreme scenarios dominates in Agrawal's empirical research, with a one standard deviation increase in Internet penetration lowering local tax rates by approximately 10 percent of the average rate. However, increased Internet usage puts upward pressure on local tax rates in places that have a high number of online firms with nexus. The positive effects in some jurisdictions provide policymakers with evidence that the Internet can facilitate tax collection, which may become more important as more online firms have physical presence

Given the existing evidence, the Internet need not be parasitic and it is not clear that more actively enforcing the destination principle will allow all jurisdictions to raise their tax rates especially if other tax-free opportunities exist (perhaps from online vendors abroad).

\section{Destination and Origin Taxation}

As noted in Keen and Wildasin (2004), the destination principle is usually viewed as superior to the origin principle ${ }^{23}$ but this need not be true with non-cooperative tax settings (Lockwood, 1993), imperfect competition (Keen and Lahiri, 1998), and a lack of revenue transfers. ${ }^{24}$ Does e-

\footnotetext{
${ }^{23}$ For the non-competitive tax setting, Diamond and Mirrlees (1971) suggests that the destination principle is preferred on production efficiency grounds with competitive firms. However, Keen, Lahiri, and Raimondos-Møller (2002) show that harmonization of taxes may be Pareto improving under the destination principle but is definitely Pareto worsening when the preferences of the countries are identical and taxes are levied under the origin principle. ${ }^{24}$ Fox and Yang (2016) use the state corporate income tax apportionment formula to demonstrate that movement towards destination taxation enhances economic growth and tax revenues, though the economic effects are modest and are concentrated in the manufacturing sector.
} 
commerce create an additional exception to the standard view that destination taxation is superior? Although origin taxation will eliminate use tax compliance issues by shifting tax remittance on remote sales from consumers to firms, origin taxation could trigger intense tax competition for remote firms. While the distribution of firms may be more equal, tax revenues may be lower under the origin principle (Behrens, Hamilton, Ottaviano, and Thisse, 2009). However, we agree with Keen and Hellerstein (2010) that the case for destination taxation remains strong on production efficiency grounds and recent reform in the European Union on the taxation of digital products suggests that many policymakers share this view. Indeed many of the caveats above that make the destination principle less preferred could be better addressed by interjurisdictional transfers and anti-trust policy than by a switch to the origin principle. Tax complexity issues that arise under the destination principle can also be addressed by simplifications to the tax system. ${ }^{25}$

The origin and destination principle may also have important equity concerns across space. Behrens, Hamilton, Ottaviano, and Thisse (2009) show that the origin principle intensifies tax competition and reduces tax revenues relative to the destination principle. However, the origin principle also results in a more spatially equal distribution of economic activity. Intuitively, the switch from the destination to the origin principle provides firms with an incentive to locate in low-tax regions and the effect is amplified by the fact that under the origin principle these lower rates apply for all consumers to which the product is sold (while for the destination principle, the low tax rate only applies to local consumers); this reduces excessive agglomeration. For a federal system such as the United States, how e-commerce transactions are taxed may also have important equity concerns across big cities and smaller municipalities.

\footnotetext{
${ }^{25}$ One example is the "mini one-stop shop" established in the European Union that we discuss later in the paper.
} 


\section{Efforts to Enforce Destination Taxation in the European Union}

One of the major goals of this paper is to link the policy reforms discussed abroad to reforms in the United States. Although the VAT system poses some unique challenges, the decentralized nature of the European system poses some similarities to taxes by U.S. states.

Reforms of the origin and destination principle have been addressed in Europe and other federal states with decentralized tax systems such as India, Brazil, and Canada (Mintz, 1995; Bird, 2012). ${ }^{26}$ More recently, the $\operatorname{OECD}(2014,2015)$ proposed guidelines for the structure of VAT in a digital world that unequivocally endorse the destination principle as the appropriate place-of-taxation rule for consumption taxation of cross-border trade. Many of the OECD guidelines focus on tax collection by suppliers rather than buyers, similar to the use taxes, because tax remittance by buyers likely becomes a "tax on honesty" (Hellerstein, 2015). These reforms offer some suggestions in how US practices can be improved.

A search of recent newspaper articles discussing online transactions suggests that recent surges in e-commerce and digital products have motivated other countries to reconsider their commodity tax structures. ${ }^{27}$ Some countries previously required consumers to self-assess taxes on e-commerce transactions; in other countries, e-commerce transactions were exempt if under a certain value. Newspaper articles also suggest that companies may have reduced both VAT and corporate income tax liabilities by funneling digital products through low-tax rate countries. Thus, prior to the reforms, corporate tax havens, such as Luxembourg, provided firms like Amazon with a dual benefit because of the favored VAT rate on items such as e-books.

\footnotetext{
${ }^{26}$ See for example, Mintz (1995), Bird (2012), and Keen and Smith (1996). Bird notes, "Quebec is the only subnational jurisdiction in the world to operate a destination-based VAT." Bird and Gendron (1998) argue that destination based VATs are possible in a federal system and may help alleviate cross-border trade problems when accompanied with a federal VAT.

${ }^{27}$ Appendices summarizing these findings are available from the authors.
} 
We begin discussing the history of the various VATs with an emphasis on countries within the European Union. The second VAT directive of 1967 supported the idea that the destination principle be applied to goods, but like sales taxes generally, had services taxed based on the supplier's location. In this pre-Internet era, most consumption and supply of services occurred within the same country, which generally preserved the spirit of the destination principle (Hellerstein and Gillis, 2010). Furthermore, enforcing the destination principle prior to the EU common market was relatively effective given the presence of border controls.

However, the elimination of border controls within the EU in 1993 raised several challenges similar to the presence of open borders across U.S. states. Reforms in the EU have been primarily top down while those in the U.S. have been primarily bottom up, beginning with the states. Following the opening of borders, the VAT enforcement mechanisms at country borders were replaced with administrative requirements on EU traders. For business to consumer transactions, under a distance-selling rule, suppliers with sales greater than a particular threshold (either 100,000 or 35,000 euros) into the particular destination state are required to register for VAT in the destination country. Suppliers with sales under that threshold are not required to register in the destination country. Thus, some remote transactions occurring within the European Union are taxed at origin when the supplying firm is small. These distance selling rules applied to goods ordered over the Internet but physically shipped; digital goods (those downloaded by the consumer) fell under alternative rules. This distance selling rule has a similar spirit to the Marketplace Fairness Act in the United States, which requires firms to collect use taxes regardless of physical presence if sales are above a total threshold. One difference, however, is that the Marketplace Fairness Act apples a threshold on total sales whereas distance selling rules in the EU require the firm to satisfy the threshold in each state individually. 
The prior rule of taxing services at origin became problematic as electronic consumption of services increased and services were delivered remotely. Indeed, the digital era made it so that intangible services such as legal, financial, and telecommunication services, among others, have no clear place of consumption (Hellerstein and Gillis, 2010). In 2003, under the EU ecommerce directive, digital suppliers outside of the Union were required to comply with VAT based on the consumer's location. At the same time, the EU adopted simplified registration processes in an effort to reduce costs associated with collection at destination. However, over this period, digital providers such as Amazon began to cluster in Luxembourg, which has a reduced rate for e-books. Corporate taxes also provided incentives for these companies to locate within Europe. In the 2007 VAT Package, the European Union required that the taxes on digital products be assessed on the destination basis for the majority of digital transactions occurring within the Union. This package was an effort at taxing digital services at the place of consumption. It has been reported that firms like Netflix have begun to change their business model in response. Some of these added complexities for digital products are less necessary for many states' sales taxes because many services are not covered, although as early as 2003 some U.S. states introduced taxes on digital downloads. Thus, implementation of the destination principle in this arguably more complex system has important lessons for the United States. A main source of opposition to collecting taxes on digital products based on the destination principle was added complexity for firms that would need to comprehend and collect taxes for several nation-states. To overcome this complexity, the EU adopted a "mini one-stop shop" (MOSS) that allows firms to submit a single quarterly return to the tax authority of the country where the supplier is located. This country then redistributes the tax revenue appropriately to other member states of the EU on a destination basis and in accordance with the 
return filed by the firm. In addition to the simplicity of filing only one return, companies are only required to register for VAT in the home country, which saves on administrative costs.

The policy reform to digital products had winners and losers, with Luxemburg likely the largest loser. However, to be implemented, the proposal required no member states to object. In the short-run Luxemburg is being compensated with relatively large additional redistributive grants to overcome this obstacle.

Of course, above and beyond the issue of whether B2C online transactions should be taxed, the location where consumption actually occurs may have some ambiguity. This especially raises issues where small local jurisdictions may have taxing authority as in the United States. In the EU context, Hellerstein (2015) summarizes rules for determining or proxying for the place of consumption. First, OECD (2015) acknowledges some consumption occurs where it is supplied and the OECD guidelines suggest standard taxation rules apply to these transactions. However, OECD (2015) groups all other transactions (such as consulting, broadcast services, online supply of digital content, etc.) under a "usual residence rule." Under this rule, consumption need not be assigned to precisely where it actually occurs; rather the supplier should use available information at hand such as customer address, bank details, credit card information, IP addresses, etc. to proxy for the consumption location (Hellerstein, 2015). Such guidelines may be problematic under a system of local taxation in the United States when bank details, credit card details, and customer address may all be in different localities. To overcome high compliance costs, OECD (2015) suggests simplified registration and returns similar to the MOSS, electronic payments, and the use of third party providers to reduce tax compliance costs. This guideline has a similar flavor to the Marketplace Fairness Act and Streamlined Sales and Use Tax Agreement, though a MOSS is not currently envisioned in the U.S. 
VAT evasion and avoidance remain in the presence of open borders. Carousel fraud, for example, may amount to approximately ten percent of net VAT receipts in some countries (Keen and Smith, 2007). After the removal of border controls, VAT on imports is no longer collected at the border, but rather is deferred until the next periodic return. Carousel fraud is the process whereby firms exploit the fact that exports are zero-rated and invoices and payments of taxes occur at different time. In particular, to complete the fraud, one registered traded goes "missing" with respect to remitting the VAT to the tax authority (Keen and Smith, 2007). ${ }^{28}$ Given the absence of border controls, similar problems would arise if US states were to adopt VATs .

Reverse charging places liability for remitting the tax on the buyer rather than the seller and indeed the UK has adopted reverse charging on goods that have a reputation for carousel fraud (Keen and Smith, 2007). However, most countries have opposed such a solution given that, if adopted on many commodities, it may turn the VAT into a RST.

Other non-administrative solutions to such fraud include the adoption of a CVAT or VIVAT, which also have relevance to the U.S. decentralized commodity tax system; these systems - whether adopted in the EU or U.S. are not immune to issues arising from e-commerce. Under the CVAT (McLure, 2000), states may levy different VAT rates that apply to sales within state; however inter-state sales are zero rated from the state VAT and instead subject to a uniform "compensating VAT" rate. With regard to e-commerce, the compensating VAT rate may apply to all digital transactions of intangibles - even transactions that may occur between a buyer and seller in the same state - given that substantial difficulties exist in determining the location of the buyer. However, physical products purchased online could be distinguished as

\footnotetext{
${ }^{28}$ Some proposed solutions to carousel fraud include conducting background checks or site visits of firms registering for VAT and making firms that are aware of the fraud liable for some of the lost revenue.
} 
inter-state or intra-state and thus intra-state transactions subject to the state rate and inter-state transactions subject to the compensating rate. ${ }^{29}$

The VIVAT (Keen and Smith, 2000) is an alternative that would establish a uniform rate on all business to business transactions regardless of whether they are inter-state or intra-state. At the same time, the rate applied to final sales would be left at the state VAT rate. Keen and Smith (2000) argue that the VIVAT system is preferred because it symmetrically treats intra- and inter-state business to business transactions yielding the same compliance costs regardless of the type of transaction. Such symmetry may be valuable in the presence of e-commerce when orders may be placed in one state for delivery in another. Thus, given the added difficulty the Internet creates in terms of identifying the location of an intermediate business, a system treating intraand inter-state transactions similarly would seemingly be preferred. Of course, any VIVAT system still has borders outside of the federation's (EU or USA, for example).

The lessons of the European Union experience suggest that: (1) It is administratively possible to tax digital products based on the destination principle even in a decentralized "federation." (2) Destination taxation of e-commerce may be politically feasible if "losing" member states are provided some compensation in the transition to the new regime. (3) In some sense, issues of e-commerce under a VAT are more complex than the RST given that many intangible services are subject to a VAT but not to the sales tax. The EU's ability to establish reforms for both goods and services suggests that the U.S. failure to resolve the issue is primarily political. (4) Enforcement of destination taxation is not perfect and fraud, avoidance and evasion

\footnotetext{
${ }^{29}$ Of course, e-commerce presents some additional concerns for the CVAT that were even recognized at the time of its proposal. At what level should the compensating rate be set? If set at the rate of the lowest state VAT rate in the federation, households may shift to mail-order or e-commerce transactions that are subject to the low-tax CVAT. This is problematic if e-commerce is a substantial portion of transactions and if the lowest state tax rate is well below the average tax rate. A minimum state tax rate would reduce the problem but may not be feasible in the United States. Setting the compensating rate at the highest state tax rate reduces the incentive to buy online, but may burden interstate commerce (McClure, 2000).
} 
will still arise. In particular, the tax authority must maintain a balance between the intensity of administering the tax and the tax revenue leakages arising from evasion. (5) Our understanding of subnational tax systems such as the VIVAT and CVAT has advanced substantially, but ecommerce challenges these systems. We believe that a tax system should not create a preference for electronic transactions, especially when tax rates vary substantially across states.

Reforms of the taxation of digital products are not limited to the European Union. As of 2015, over 35 countries have introduced new rules on digital products, although many have not been adopted as yet. For example, New Zealand has proposed the collection of GST on digital services that includes a requirement for the tax to be remitted by out-of-state firms and in exchange grants a simplified registration process. Australia proposed a similar GST on digital services in 2015. Japan also implemented a requirement for taxation of business to consumer ecommerce while also creating a registration system where out-of-state suppliers designate an agent in Japan for purposes of tax compliance. These issues are not constrained to developed countries. South Africa passed rules requiring collection on business to consumer e-commerce in 2014 and approximately 80 foreign firms have registered in the first year, which the government deems a success. Even the Central Bank of India has suggested it will be important to tax e-commerce. Brazilian states levy origin taxes on $\mathrm{B} 2 \mathrm{C}$ sales, but recently enacted an additional destination tax on cross-state e-commerce sales. The tax is collected by origin firms and was enacted to share some of the revenues with destination states. The approach was adopted because of concerns that Sao Paulo State was receiving most of the revenues from final ecommerce sales.

One common theme among many of these proposals and practices, however, is increased simplification of registration requirements, which may be akin to requirements in the U.S. for 
states to simplify their tax systems. ${ }^{30}$ Switzerland has proposed reducing the VAT compliance threshold to zero for other digital products in the future, suggesting the exemption threshold in the Marketplace Fairness Act might not need to be permanent.

\section{Efforts to Enforce Destination Taxation in the United States}

Economists have recognized the importance of enforcing destination taxation to reducing "harmful" tax competition for shoppers. Origin based taxes, on the other hand, shift the focus to competition for sellers, ${ }^{31}$ which may be more mobile than buyers making zero-tax states more attractive. ${ }^{32}$ Policy changes in most states and the EU focus on improving means of enforcing destination taxation, both to raise revenues and to protect in-state retailers. Spurred by rapidly rising e-commerce, a range of bottom-up approaches to enhancing destination taxation through better enforcement have been adopted or proposed in recent years. These include expanding the definition of nexus, requiring third party information, seeking passage of the Marketplace

Fairness Act, encouraging large e-tail firms to locate within the state or voluntarily remit taxes, requiring use tax reporting on individual income tax returns and relitigating the Supreme Court decision on the need for physical presence. Each of these is briefly discussed below.

\section{A. Do Nothing or Encourage Firms to Locate in State}

Large companies like Amazon.com have begun entering into more markets (for example, as of October 2014, Amazon collects sales taxes in 23 states). One reason for this is Amazon believes

\footnotetext{
${ }^{30}$ Taxamo, a commodity tax compliance firm, tracks changes in the taxation of digital software for its clients. The tax changes summarized in this paragraph are explained in more detail on their websites "International Plans for the Taxation of Digital Services" and "International Digital Tax Laws."

${ }^{31}$ Bruce, Fox, and Luna (2015) provide evidence that higher sales tax rates reduce the tendency to create nexus in a state, but that size of the market is the most important factor in determining the states where firms choose to locate.

${ }^{32}$ Such a policy in the United States is likely to have many different winners and losers so that it is unlikely such an agreement would take place. Nonetheless, Congressman Bob Goodlatte, Chairman of the U.S. House of Representatives Judiciary Committee, has proposed an origin based tax on online sales. The tax would be collected by the origin state at the origin state's rate, but the revenues would be distributed to the destination state.
} 
that consumers place a high value on the time taken to receive the goods. ${ }^{33}$ If this characteristic of goods is important, it suggests that remote vendors may find it more profitable to establish physical presence in large states (consistent with Bruce, Fox and Luna, 2015) and states that provide strategic transportation hubs. Under this model, firms would explicitly establish physical presence in more markets over time, which will facilitate tax collection even if the states or federal government do nothing. ${ }^{34}$

The strategy of entering into many state markets is likely only profitable for large companies that have sufficient funds to finance fixed costs or for companies that are already present in many states by virtue of having a bricks and mortar channel through which they operate. So, the tendency to collect sales tax for multiple states may correlate with firm size. States might create incentives to try to lure e-tail companies to locate in their state. While lowering the sales tax rate might have some effect, other explicit mechanisms exist to target firms - often times specific firms. For example, some companies have lobbied for tax exemptions in exchange for building a site in a particular state. Amazon agreed to build distribution centers in Indiana, California, South Carolina, Tennessee and New Jersey in exchange for delays in the requirement to collect sales taxes. Although this increases taxable transactions in the state in the long-run, it is a form of fiscal competition where states compete with incentives by "bidding for firms".

\section{B. Nexus Rules}

\footnotetext{
${ }^{33}$ Amazon is collecting in some of these states because of changes in state laws and in others because of decisions by Amazon. See "Which States Make You Pay an Amazon Sales Tax," Wall Street Journal, October 1, 2014.

${ }^{34}$ Some businesses might structure their local presence as a separate corporate entity (albeit controlled by the out-ofstate vendor), which sometimes allows vendors to have it both ways, at least in the absence of legislation or case law establishing that the presence of an affiliate in the state constitutes sufficient nexus for tax collection purposes.
} 
Bellas Hess and Quill limit states to imposing a collection responsibility on firms that have nexus within the state. The Supreme Court concluded that requiring firms without physical presence to collect the sales tax violated the dormant Commerce Clause as it placed an undue burden on remote firms because of compliance costs associated with managing multiple state and local tax systems. The notion was that a remote firm might be required to collect tax for many states (and possibly thousands of local governments) and could bear higher compliance costs than a local firm that must comply only with the administrative procedures for a single state. Nexus within a state also implies nexus for all local taxes throughout the state because local jurisdictions do not enjoy a separate identity from the state for federal constitutional purposes.

Many efforts to enforce destination taxation focus on states defining physical presence broadly. Differing practices across the states likely raise compliance costs. Nexus is clearly created by owning or leasing property in a state, but a number of states have sought much more expansive nexus rules. The presence of employees in a state (such as salespeople), sometimes for modest periods of time, is presumed to create nexus by some states. Storing goods in a warehouse, shipping in-process inventory for further processing or having vehicles in the state establish nexus in many places. Some states even determine nexus by firms being in the local phone book, having a local phone number or having a local bank account.

Attributional nexus has been the next wave of expansive nexus laws. Attributional nexus arises when states assert nexus over a firm because it has a relationship with another firm that has physical presence in the state. Use of the same trademark or name, such as Walmart and Walmart.com, with Walmart.com presumed to have nexus because Walmart stores are present. Another example is when nexus is asserted over companies because they use in-state firms to install or maintain the remote firm's product in the state. 
"Click-through-nexus" or so called "Amazon Laws" have been enacted in approximately 25 states. These laws assert nexus over e-commerce companies that have affiliates with nexus in the state that direct sales to the e-commerce firm's website and receive a percentage of the sales price in return. As an example, Amazon might place an online advertisement on Firm Z's website and if Firm $\mathrm{Z}$ has physical presence, then Amazon may also have nexus.

Changes to nexus definitions may target specific firms without resolving the fundamental issue of tax collection because individuals may simply substitute their purchases to other "taxfree" websites. Baugh, Ben-David and Park (2014) find that expenditures on Amazon.com fall by 9.5 percent, brick-and-mortar sales increase 2 percent, and competing online retailers' purchases increase 19.8 percent after Amazon Laws go into effect. This result suggests that online purchases of the same product from different websites are likely to be strong substitutes and consumers are more interested in product attributes than characteristics of the vendor. Although these click-through nexus laws trigger small gains for in-state brick-and-mortar sellers, the tax revenue implications for the state are perhaps not as large as expected because of the relatively elastic response to alternative online platforms not captured under the Amazon law.

\section{Information Reporting}

A few states require information reporting when they cannot require tax collection. With information sharing legislation, the state requires vendors without nexus to provide third party information on the total amount of sales by their customers but do not require the vendor to determine taxability or remit the tax. For example, Amazon agreed to send information to every Tennessee purchaser on the dollar amount of sales during the year and to note that the purchases may be subject to the use tax. Such a policy is designed to reduce the transaction cost for consumers to identify their online purchases for use tax filing and potentially to provide 
information that the state can use to audit buyers. The agreement lasted for three years until Amazon began collecting the tax on behalf of Tennessee. ${ }^{35}$ Colorado's law requires firms that do not collect the sales tax to report the dollar amount of sales to the state revenue department, which can use the third party information during an audit in an effort to identify buyers who may owe use tax. The statute has been challenged in court and the Supreme Court recently decided one element of the case (specifically, that the case could be heard in a federal as opposed to a state court), in an infrequent consideration of a state tax case by the national court (Direct Marketing Association v. Brohl, 135 S. Ct. 1124 (U.S. 2015)). The 10 $0^{\text {th }}$ U.S. Court of Appeals subsequently concluded that Colorado could enforce the information requirement.

If use tax non-compliance results from a lack of information by the taxpayer about their online purchases and whether they need to file use taxes on them, then requiring firms to educate taxpayers by informing them of their purchases can be beneficial to the tax authority. The literature on providing individual income tax information to taxpayers is much larger, but some studies have analyzed information about the use tax. For example, Anderson (2014) worked with the state of Nebraska to randomly mail postcards to taxpayers reminding them about the use tax and providing information on the types of transactions that need to be reported. He finds small positive effects, though ones that are just large enough to cover the full cost of selecting and mailing the postcards. This suggests that when the costs are incurred by the vendor, as in the Tennessee case, the potential exists to increase tax compliance.

In the case of the Colorado law, information is provided to both the tax authority and the consumer. For a given amount of resources allocated to tax audits of use tax returns, third-party

\footnotetext{
${ }^{35}$ Tennessee and Amazon agreed that the presence of several fulfillment centers would not be used to establish nexus for three years, after which Amazon would begin to collect the tax on Tennessee purchasers. Initial analysis suggests an increase in use tax returns in each month when the emails were sent, but erosion in subsequent months.
} 
reporting would increase the risk of being detected and increase compliance. Naritomi (2014) provides evidence that third-party reporting of receipts facilitates Value Added Tax compliance in Brazil. Under the Value Added Tax, firms report their tax liability to the state; if the firm does not issue a receipt to the customer, no third party reporting exists and the firm might evade some taxes. Sao Paulo Brazil implemented a program, "Nota Fiscal Paulista," that provided consumers with monetary incentives if they asked for a receipt and uploaded it to a website. The program is estimated to increase revenue in the retail sectors by 22 percent. In the Brazilian case, the consumer acts as a tax auditor by making sure that a paper trail exists for the tax authority. The Colorado law is similar in that it requires the firm to act as a third-party provider of information, which should increase compliance by consumers.

\section{Income Tax Filing}

Thirty-eight states levy both a state income tax and a state sales tax. Twenty-five states allow individuals to report their use tax liability on their income tax return. Several additional states provide information on use tax liability in their income tax instruction booklet. According to Manzi (2012), relatively few taxpayers use the income tax return as an opportunity to file their use tax liability, and most simply do not comply with the law. In particular, the average use tax reported per return ranges from $\$ 12$ to $\$ 202$ with between $0.3 \%$ of returns and $9.8 \%$ of returns reporting nonzero revenues. In 2009 , this collection via the income taxes amounted to $\$ 10.2$ million dollars in revenue and \$34.6 million in California and New York, respectively; this is a small amount relative to total collections.

States try a variety of mechanisms to enhance compliance through the income tax return. Some require taxpayers to explicitly indicate " 0 " liability if a positive value is not reported, some provide tables to look up the liability associated with various estimates on taxable purchases on 
which the use tax may be due, and some provide compliance education. The payments may be better thought of as a surcharge on income rather than sales/use tax payments in cases where the use tax liability is looked up based on income. Viewed this way, this collection method may extract additional taxes but does not particularly level the playing field vis-à-vis brick and mortar vendors. These efforts have not been studied rigorously, but casual examination suggests they may contribute modest additional revenue and that their effectiveness varies across states.

\section{E. Streamlined Sales Tax Governing Board}

In 2000, a group of states began debating the best means of enforcing destination taxation for remote sales. The discussions led to creation of the Streamlined Sales Tax Governing Board, an organization of 24 states that operates somewhat like a cartel. The Governing Board has adopted a series of tax structure, compliance, and administrative rules to which all participating states must conform. The rules include common tax returns, similar definitions of exemptions (though not the same exemptions), a single tax collector for each state, a state-provided database of all local tax rates, and other steps that reduce compliance costs. Some firms have chosen to voluntarily comply with the Governing Board and take advantage of the compliance mechanism. As a result states have accumulated several billion dollars that would otherwise not have been collected. No research has taken place into why firms voluntarily comply through the Governing Board for some states, but the staff report that complying firms have nexus in many member states (generally ones where the firms have most of their sales) and as a result the firms choose to comply in all member states. Voluntary compliance minimizes the chance that the firms could be later determined to have nexus in states for which they were not collecting. F. National Change in the Nexus Definition 
Either federal legislation ${ }^{36}$ allowing states to require remote vendors to collect the sales tax or a new U.S. Supreme Court decision reversing the requirement for physical presence is necessary if states are to require all U.S. firms selling into the state to collect the sales tax. All other approaches will fall short of requiring broad compliance on a destination basis. These two approaches differ in the sense that the Supreme Court likely would not develop precise guidelines for the new standard of taxable presence, which would lead to considerable uncertainty and likely significant cross state variation. Congress would likely define more precise rules. It is worth noting that a new decision by the Supreme Court might motivate Congress to define more precise rules. The states are moving forward to encourage a new court decision in the event that Congress does not create clear rules soon. For example, Alabama's Revenue Commissioner recently asserted that firms with more than $\$ 250,000$ in sales must begin collecting the sales tax even if they have no physical presence and South Dakota enacted legislation requiring remote firms with more than $\$ 100,000$ in sales to the state to collect the sales tax. A court challenge could result from either of these states or other states that are considering similar actions and South Dakota has already sued four large e-commerce firms.

The U.S. Senate passed the Marketplace Fairness Act of 2013 that would have permitted states to require remote vendors to collect the sales tax on their behalf. The bill is at least the fourth version introduced in Congress in recent years, but is the first to pass the Senate. Under the bill, states would be required to adopt a series of simplifications including, a single state tax rate across various commodities for each state (except for food), common definitions of

\footnotetext{
${ }^{36}$ In the Quill Corp v. North Dakota ruling, the Court specifically reaffirms that Congress has the authority to legislate what constitutes an undue burden on cross border transactions and can define when a state can impose tax on remote sales (subject to due process considerations). Congress can enact legislation that allows states to require remote firms to remit taxes and the Supreme Court encouraged Congressional action to create a bright line for nexus in the Quill decision (and more recently in Justice Kennedy's statements mentioned above).
} 
exemptions, a single sales tax administrator for the state and all local governments within each state, destination sourcing ${ }^{37}$ and access to free tax compliance software. All of these simplifications track the Streamlined Sales and Use Tax Agreement and states that are members of the Agreement are assumed to already have undertaken these steps. The intent is to link lower compliance costs to easing of the restriction on requiring remote vendors to collect the tax. The U.S. House of Representatives failed to pass the legislation and it died with the new Congress. Subsequently, the "Remote Transactions Parity Act of 2014" has been written but not introduced for hearings and a new version of the Marketplace Fairness Act, now of 2015, has been written.

Under the Marketplace Fairness Act, firms with less than $\$ 1.0$ million in U.S. ecommerce sales would be exempt from the collection responsibility, which creates a notch. The Remote Transactions Parity Act of 2014 has a $\$ 10$ million dollar small seller threshold in the first year, $\$ 5.0$ million in the second year, and \$1.0 million in the third year. Most firms' sales fall below the small seller thresholds. Bruce and Fox (2013) estimate that the \$1.0 million threshold would exclude millions of small e-commerce firms and leave fewer than 2000 firms subject to the tax. Thresholds on the basis of firm size might also create incentives for firms to bunch on the tax-favored side of the threshold. However, this bunching would likely only be economically meaningful if a significant number of firms are located in the region of the threshold. Given the numbers reported in Bruce and Fox (2013), this seems unlikely to be a concern unless new small firms arise because of a desire by households to purchase goods from smaller firms. Finding a point in the distribution where manipulation is minimized might provide some economic justification for where to place the threshold. However, firms may seek to

\footnotetext{
${ }^{37}$ Sales are sourced to the location indicated by instructions for delivery, and if these are not available, to the consumer's address or location for payment. The sale is sourced on an origin basis if none of this information is available to source on a destination basis.
} 
divide themselves into several informally linked businesses to avoid a collection responsibility (this is prohibited by the law but appears difficult to enforce).

The Marketplace Fairness Act requires that a single audit of a remote seller take place for all governments within each state, but says nothing about whether each remote firm could be subject to audit by all sales taxing states. The need for coordination by the states could be important to limit both compliance and administration costs.

\section{Conclusion and Policy Recommendations}

The digital economy and technological advances that facilitate remote transactions are raising new and important policy questions in federations with decentralized commodity taxation, including the U.S. retail sales taxes and Value Added Taxes and Goods and Service Taxes in some countries. Similar issues can also arise for international transactions. Both the U.S. and EU seek to collect consumption taxes on a destination basis, the merits of which have been discussed in the prior economics literature, and to use vendor compliance where possible to limit collection costs. Optimal tax theory, even when expanded to include administration and compliance, suggests that identical tax rates are the best policy for remote and local transactions in a local market, though considerable empirical research is needed before definitive conclusions can be reached. But, the inability to enforce destination taxation effectively across open borders has led to favored effective rates (at least in some cases) for remote e-commerce transactions.

In the United States, most reforms have been bottom up from the states and are aimed at improving enforcement of destination taxation. However, we believe U.S. states are encumbered by the physical presence standard for vendor collection and remittance of the tax, which is inconsistent with a consumption tax on digital and remote transactions. For example, the ability to ship remotely creates unique incentives for firms to strategically pick states where they desire 
to establish a physical presence. The result has been reforms that can be conducted within the existing legal structure, but which remain insufficient to collect destination taxes on many remote purchases. Further, state level-policy solutions create very different practices across the country and likely create significant compliance costs, particularly when buyer compliance is included. Reforms at the national level through either Congress (such as the Marketplace Fairness Act) or the court system appear to be the important next step that can ultimately reduce compliance costs for an effectively destination enforced series of state sales taxes. We prefer Congressional legislation that better reduces uncertainty and enhances administrative and compliance conformity across the states. Legal challenges will arise if Congress does not act in the near term to enhance state capacity to collect the sales tax. Congress may then choose to react by passing legislation that adds more certainty and consistency if the Supreme Court permits states to assert taxable presence over remote firms. Top-down national reforms are necessary given the rapidly changing technological pressures of the Internet on state tax systems.

Further, the US can learn from the EU's top down reforms on taxation of e-commerce. Recognizing that tax collection in multiple states potentially creates administrative complexities for many firms, the EU simplified compliance for digital products through cooperative administration, though the ability to enforce the rules in the U.S. context and the effects of the new margins created by the simplifications are yet to be seen. Streamlined States in the U.S. have also sought to limit compliance costs through improved processes and definitions.

Digital products can lack a place of product origin and a clearly identifiable place of use because they can be sold through a subsidiary or a headquarters in a low-tax country. Situsing where taxes should be paid and at what rate is an increasing challenge for digitized products, regardless of whether countries use origin or destination taxes or the VAT or sales tax. Rules 
based approaches will be necessary to enforce the tax and the key is to limit the distortionary effects arising from the newly created margins. As digital products continue to grow, additional issues with regard to the assessment of commodity taxes will expand requiring further reforms as well so best practices are more likely to evolve than to be fully designed upfront.

Rapidly changing technologies may present unforeseen challenges for state and local governments as well as the EU in the coming years. As they do, we hope this paper provides policymakers with guidance on how to approach these new challenges. The paper has also identified areas where future research could inform the policy debate. For example, relatively little is known about how administrative changes enhance compliance and which are most effective. The implications of taxable online sales on tax competition also remain understudied and the literature would benefit from theoretically modeling the heterogeneous effects of taxable online transactions in a tax competition setting. Also, additional research could help identify how responses to the margins created by either new administrative practices or the inability to enforce destination taxation impact behavior, such as the extent of purchasing from vendors that do not collect tax, how consumption patterns are affected by efforts to collect tax from buyers, how administrative changes alter compliance with transactions' taxes, and the extent of bunching that will result from imposition of minimums below which compliance is not required. We also recommend more research on commodity taxation reforms in countries other than the U.S.; as countries change their treatment of digital products, we believe other countries can learn from the effect of these reforms given the e-commerce poses challenges for all tax systems. 


\section{References}

Agrawal, David R. 2014. "LOST in America: Evidence on Local Sales Taxes from National Panel Data." Regional Science and Urban Economics, 49: 147-163.

Agrawal, David R. 2015 "The Internet as a Tax Haven? The Effect of the Internet on Tax Competition," SSRN Working Paper.

Alm, James and Mikhail I. Melnik. 2010. "Do eBay Sellers Comply with State Sales Taxes?" National Tax Journal, 63 (2): 215-236.

Anderson, John. 2014. "Paying the State Use Tax: Is a 'Nudge' Enough?” Public Finance Review, forthcoming.

Ballard, Charles L. and Jaimin Lee. 2007. "Internet Purchases, Cross-border Shopping and Sales Taxes," National Tax Journal, 55 (4): 711-725.

Baugh, Brian, Itzhak Ben-David and Hoonsuk Park. 2014. "The Amazon Tax: Empirical Evidence from Amazon and Main Street Retailers," NBER Working Paper.

Behrens, Kristian, Jonathan Hamilton, Gianmarco Ottaviano, and Jacques-Francois Thisse. 2009. "Commodity Tax Competition and Industry Location under the Destination and Origin Principle,” Regional Science and Urban Economics, 39: 422-433.

Bruce, Donald, and William F. Fox. 2013. "An Analysis of Internet Sales Taxation and the Small Seller Exception," Office the Advocacy, Small Business Administration, November.

Bruce, Donald, William Fox and LeAnn Luna. 2015. "E-Tailer Sales Tax Nexus and State Tax Policies," forthcoming, National Tax Journal.

Bruce, Donald, William Fox and LeAnn Luna. 2009. "State and Local Sales Tax Revenue Losses from E-commerce," State Tax Notes, May 18, 2009.

Bruce, Donald, William Fox and Matthew Murray. 2003. "To Tax or Not to Tax: The Case of Electronic Commerce," Contemporary Economic Policy, 21: 25-40.

Diamond, Peter A. and James A. Mirrlees. 1971. "Optimal Taxation and Public Production I: Production Efficiency,” American Economic Review, 61 (1): 8-27.

Einav, Liran, Dan Knoepfle, Jonathan Levin, and Neel Sundaresan. 2014. "Sales Taxes and Internet Commerce," American Economic Review, 104 (1): 1-26.

Ellison, Glenn and Sara Fisher Ellison. 2009. "Tax Sensitivity and Home State Preferences in Internet Purchasing," American Economic Journal: Economic Policy, 1 (2): 53-71.

Fox, William F. 2012. "Sales and Excise Taxes," in Robert Ebel and John E. Petersen (eds.) Oxford Handbook on State and Local Finance, Oxford University Press: New York. 
Fox, William F., LeAnn Luna, and Georg Schaur. 2014. "Destination Taxation and Evasion: Evidence from U.S. Inter-state Commodity Flows," Journal of Accounting and Economics, 57: 43-57.

Goolsbee, Austan. 2000. "In a World Without Borders: The Impact of Taxes on Internet Commerce,” Quarterly Journal of Economics, 115 (2): 561-576.

Goolsbee, Austan, Michael F. Lovenheim, and Joel Slemrod. 2010. "Playing with Fire: Cigarettes, Taxes and Competition from the Internet," American Economic Journal: Economic Policy, 2 (1): 131-154.

Hatta, Tatsuo. 1986. "Welfare Effects of Changing Commodity Tax Rates Towards Uniformity," Journal of Public Economics, 29: 99-112.

Hellerstein, Walter. 2015. “A Hitchhiker's Guide to the OECD’s International VAT/GST Guidelines." Florida Tax Review. Forthcoming.

Hellerstein, Walter and Timothy H. Gillis. 2010. "The VAT in the European Union." Tax Notes 127: 461-471.

Johannesen, Niels. 2010. "Imperfect Tax Competition for Profits, Asymmetric Equilibrium, and Beneficial Tax Havens,” Journal of International Economics, 81 (2): 253-264.

Keen, Michael and Walter Hellerstein. 2010. "Interjurisdictional Issues in the Design of VAT," Tax Law Review, 63 (2): 359-408.

Keen, Michael and Sajal Lahiri. 1998. "The Comparison Between Destination and Origin Principles Under Imperfect Competition,” Journal of International Economics, 45: 323-350.

Keen, Michael, Sajal Lahiri, and Pascalis Raimondos-Møller. 2002. "Tax Principles and Tax Harmonization Under Imperfect Competition: A Cautionary Example," European Economic Review, 46: 1559-1568.

Keen, Michael and Stephen Smith. 1996. "The Future of Value Added Tax in the European Union," Economic Policy, 11 (23): 373-420.

Keen, Michael and Stephen Smith. 2000. "Viva VIVAT!" International Tax and Public Finance 7: $741-751$.

Keen, Michael and Stephen Smith. 2007. "VAT Fraud and Evasion: What Do We Know, and What Can Be Done?” IMF Working Paper 07/31.

Keen, Michael and David Wildasin. 2004. "Pareto-Efficient International Taxation," American Economic Review, 94 (1): 259-275. 
Lockwood, Ben. 1993. "Commodity Tax Competition Under Destination and Origin Principles," Journal of Public Economics, 52 (2): 141-162.

Manzi, Nina. 2012. "Use Tax Collection on Income Tax Returns in Other States," Policy Brief, Minnesota Department of Representative, Research Department, April.

Mazerov, Michael. 2013. "States Should Embrace $21^{\text {st }}$ Century Economy by Extending Sales Taxes to Digital Goods and Services," State Tax Notes, 35-52, January 7.

McLure, Charles E. 2000. "Implementing Subnational Value Added Taxes on Internal Trade: The Compensating VAT (CVAT)," International Tax and Public Finance, 7 (6): 723-740.

McLure, Charles E. 2003. "The Value Added Tax on Electronic Commerce in the European Union,” International Tax and Public Finance, 10: 753-762.

Naritomi, Joana. 2014. "Consumers as Tax Auditors,” Working Paper.

OECD. 2014. "Addressing the Tax Challenges of the Digital Economy" OECD/G20 Base Erosion and Profit Shifting Project, OECD Publishing.

OECD. 2015. "International VAT/GST Guidelines.” OECD Publishing.

PriceWaterhouseCoopers. 2007. "Retail Sales Tax Compliance Costs: A National Study," Joint Cost of Collection Study, June 1.

Slemrod, Joel. 1990. "Optimal Taxation and Optimal Tax Systems," Journal of Economic Perspectives, 4: 157-178.

Slemrod, Joel and John D. Wilson. 2009. "Tax Competition with Parasitic Tax Havens," Journal of Public Economics, 93 (11-12): 1261-1270.

State of Washington. 2010. "Department of Revenue Compliance Study," Research Report No. 2010-4, August 20.

Tosun, Mehmet S. and Mark L. Skidmore. 2007. "Cross-Border Shopping and the Sales Tax: An Examination of Food Purchases in West Virginia," The B.E. Journal of Economic Analysis \& Policy, 7(1): 1-18.

Wildasin, David E., 2001. "Sales Taxation in Kentucky: Problems and Prospects," In: Wildasin, David E., Childress, Michael T., Hackbart, Merl, Lynch, Lawrence K., Martie, Charles W. (Eds.), Financing State and Local Government: Future Challenges and Opportunities. Kentucky Long Term Policy Research Center, pp. 27-38.

Zodrow, George. 2006. "Optimal Commodity Taxation of Traditional and Electronic Commerce,” National Tax Journal, 59, 7-31. 